\title{
High entropy defective fluorite structured rare-earth niobates and tantalates for thermal barrier applications
}

\author{
Zifan ZHAO ${ }^{a, b}$, Heng $\mathrm{CHEN}^{a}$, Huimin XIANG ${ }^{a}$, Fu-Zhi DAI ${ }^{a}$, Xiaohui $\mathrm{WANG}^{c}$, \\ Wei XU' ${ }^{d}$, Kuang $\mathrm{SUN}^{d}$, Zhijian $\mathrm{PENG}^{b, *}$, Yanchun $\mathrm{ZHOU}^{a, *}$ \\ ${ }^{a}$ Science and Technology on Advanced Functional Composite Laboratory, Aerospace Research \\ Institute of Materials \& Processing Technology, Beijing 100076, China \\ ${ }^{b}$ School of Engineering and Technology, China University of Geosciences, Beijing 100083, China \\ ${ }^{c}$ Shenyang National Laboratory for Materials Science, Institute of Metal Research, \\ Chinese Academy of Sciences, Shenyang 110016, China \\ ${ }^{d}$ Shanghai Chenhua Science and Technology Corporation Ltd., Shanghai 201804, China
}

Received: January 22, 2020; Revised: February 14, 2020; Accepted: February 15, 2020

(C) The Author(s) 2020.

\begin{abstract}
Rare-earth tantalates and niobates $\left(\mathrm{RE}_{3} \mathrm{TaO}_{7}\right.$ and $\left.\mathrm{RE}_{3} \mathrm{NbO}_{7}\right)$ have been considered as promising candidate thermal barrier coating (TBC) materials in next generation gas-turbine engines due to their ultra-low thermal conductivity and better thermal stability than yttria-stabilized zirconia (YSZ). However, the low Vickers hardness and toughness are the main shortcomings of $\mathrm{RE}_{3} \mathrm{TaO}_{7}$ and $\mathrm{RE}_{3} \mathrm{NbO}_{7}$ that limit their applications as TBC materials. To increase the hardness, high entropy $\left(\mathrm{Y}_{1 / 3} \mathrm{Yb}_{1 / 3} \mathrm{Er}_{1 / 3}\right)_{3} \mathrm{TaO}_{7},\left(\mathrm{Y}_{1 / 3} \mathrm{Yb}_{1 / 3} \mathrm{Er}_{1 / 3}\right)_{3} \mathrm{NbO}_{7}$, and $\left(\mathrm{Sm}_{1 / 6} \mathrm{Eu}_{1 / 6} \mathrm{Y}_{1 / 6} \mathrm{Yb}_{1 / 6} \mathrm{Lu}_{1 / 6} \mathrm{Er}_{1 / 6}\right)_{3}\left(\mathrm{Nb}_{1 / 2} \mathrm{Ta}_{1 / 2}\right) \mathrm{O}_{7}$ are designed and synthesized in this study. These high entropy ceramics exhibit high Vickers hardness $(10.9-12.0 \mathrm{GPa})$, close thermal expansion coefficients to that of single-principal-component $\mathrm{RE}_{3} \mathrm{TaO}_{7}$ and $\mathrm{RE}_{3} \mathrm{NbO}_{7}\left(7.9 \times 10^{-6}-10.8 \times 10^{-6}{ }^{\circ} \mathrm{C}^{-1}\right.$ at room temperature), good phase stability, and good chemical compatibility with thermally grown $\mathrm{Al}_{2} \mathrm{O}_{3}$, which make them promising for applications as candidate TBC materials.
\end{abstract}

Keywords: high entropy ceramics; defective fluorite structure; rare-earth niobates/tantalates; thermal barrier coating material

\section{Introduction}

Thermal barrier coatings (TBCs) have widely been used in the gas-turbine engines to improve the energy efficiency and protect the hot structure components from foreign particle impact, water vapor, and molten

\footnotetext{
* Corresponding authors.

E-mail: Z. Peng, pengzhijian@cugb.edu.cn;

Y.Zhou, yczhou@alum.imr.ac.cn
}

salt corrosion [1-6]. However, the harsh service conditions immensely restrict the selection of TBC materials. Generally, there are several basic requirements for the selection of TBC materials, including high thermal stability, low thermal conductivity, high thermal expansion coefficient matching with the metal substrate, good corrosion resistance, and sluggish sintering rate [7-9].

Currently, the state-of-the-art TBC material is yttria-stabilized zirconia (YSZ) due to its outstanding mechanical and thermal properties, such as high strength 
and toughness, high melting point, close thermal expansion coefficient to that of metal substrate, and low thermal conductivity [10-12]. The major disadvantage of YSZ is the phase transformation, which leads to the abrupt volume change and coating cracking at higher temperatures such that the long-term service temperature is restricted to below $1200{ }^{\circ} \mathrm{C}$ [13]. Moreover, the severe sintering and high oxygen conductivity also limit its application in higher operation temperatures $[7,14]$. In order to further increase the operating temperatures of gas-turbine engines, several types of new TBC materials such as $\mathrm{RE}_{2} \mathrm{Zr}_{2} \mathrm{O}_{7}, \mathrm{RE}_{3} \mathrm{NbO}_{7}$, and $\mathrm{RE}_{3} \mathrm{TaO}_{7}(\mathrm{RE}=$ rare earth element $)$ with better thermal stability and lower thermal conductivity have been proposed [15-17]. In particular, rare-earth tantalates $\left(\mathrm{RE}_{3} \mathrm{TaO}_{7}\right)$ and rare-earth niobates $\left(\mathrm{RE}_{3} \mathrm{NbO}_{7}\right)$ have attracted enormous attention in recent years. The crystal structures of $\mathrm{RE}_{3} \mathrm{TaO}_{7}$ and $\mathrm{RE}_{3} \mathrm{NbO}_{7}$ are variable with the change of the containing REs. For $\mathrm{RE}_{3} \mathrm{TaO}_{7}$, when $\mathrm{RE}$ is La-Dy or $\mathrm{Y}$, the crystal structure is ordered orthorhombic, while the crystal structure of the rest ( $R E$ is Ho-Lu) is defective fluorite, which is analogous to that of $\mathrm{Y}_{2} \mathrm{Zr}_{2} \mathrm{O}_{7}[18,19]$. Similarly, with the decrease of ionic radius of REs, the crystal structure of $\mathrm{RE}_{3} \mathrm{NbO}_{7}$ changes from orthorhombic weberite $(\mathrm{La}-\mathrm{Tb})$ to defective fluorite (Dy-Lu, Y) [19-21]. More importantly, due to the combination of many intriguing properties, such as good thermal stability, large thermal expansion coefficients, simple crystal structure but extremely low thermal conductivity, $\mathrm{RE}_{3} \mathrm{TaO}_{7}$ and $\mathrm{RE}_{3} \mathrm{NbO}_{7}$ have been considered as promising TBC materials for higher temperature applications $[16,17]$. Nevertheless, previous studies indicate that the mechanical properties of $\mathrm{RE}_{3} \mathrm{TaO}_{7}$ and $\mathrm{RE}_{3} \mathrm{NbO}_{7}$, such as Vickers hardness, are significantly lower than those of YSZ [17,22-24]. Moreover, some compounds such as $\mathrm{Sm}_{3} \mathrm{TaO}_{7}$ and $\mathrm{Sm}_{3} \mathrm{NbO}_{7}$ exhibit phase transition with an abrupt volume change at 942 and $817{ }^{\circ} \mathrm{C}$, respectively, which is unfavorable to their application as TBC materials $[22,25]$.

It is well known that the pursuits of superior performance, for instance, the combination of higher strength, good phase stability, lower thermal conductivity, and lower sintering rate are of critical interest for developing novel TBC materials. Recently, a new class of ceramics containing multi-principal elements have attracted growing interest, which are known as high entropy ceramics (HECs) because of their high configurational entropy [26-28]. Compared with the single principal-component ceramics, HECs exhibit fascinating properties like lower thermal conductivity, sluggish grain growth rate, better water-vapor resistance, and tunable thermal expansion coefficient [29-36]. The unique properties of HECs indicate that there is a new window for developing TBC materials, i.e., designing and synthesizing high entropy (HE) TBC materials with superior performance.

To improve the properties of $\mathrm{RE}_{3} \mathrm{TaO}_{7}$ and $\mathrm{RE}_{3} \mathrm{NbO}_{7}$ for thermal barrier application and overcome the possible phase transition, $\mathrm{HE} \mathrm{RE}_{3} \mathrm{TaO}_{7}, \mathrm{RE}_{3} \mathrm{NbO}_{7}$, and $\mathrm{RE}_{3}$ $\left(\mathrm{Nb}_{1 / 2} \mathrm{Ta}_{1 / 2}\right) \mathrm{O}_{7}$, i.e., $\left(\mathrm{Y}_{1 / 3} \mathrm{Yb}_{1 / 3} \mathrm{Er}_{1 / 3}\right)_{3} \mathrm{NbO}_{7},\left(\mathrm{Y}_{1 / 3} \mathrm{Yb}_{1 / 3} \mathrm{Er}_{1 / 3}\right)_{3}$ $\mathrm{TaO}_{7}$, and $\left(\mathrm{Sm}_{1 / 6} \mathrm{Eu}_{1 / 6} \mathrm{Y}_{1 / 6} \mathrm{Yb}_{1 / 6} \mathrm{Lu}_{1 / 6} \mathrm{Er}_{1 / 6}\right)_{3}\left(\mathrm{Nb}_{1 / 2} \mathrm{Ta}_{1 / 2}\right) \mathrm{O}_{7}$, are designed and successfully synthesized in this study. The choose of these REs is due to the following reasons. Firstly, the compounds containing these REs possess similar crystal structures. Secondly, the difference of ion radius of these REs is small $(<15 \%$, Table 1$)$, which warrants the easy formation of phase-pure solid solution. Moreover, the selecting compounds (such as $\mathrm{Y}_{3} \mathrm{TaO}_{7}, \mathrm{Y}_{3} \mathrm{NbO}_{7}, \mathrm{Er}_{3} \mathrm{NbO}_{7}$, and so on) have been studied, which makes the comparison of the properties of $\mathrm{HE} \mathrm{RE}_{3} \mathrm{TaO}_{7}, \mathrm{RE}_{3} \mathrm{NbO}_{7}$, and $\mathrm{RE}_{3}\left(\mathrm{Nb}_{1 / 2} \mathrm{Ta}_{1 / 2}\right) \mathrm{O}_{7}$ with them convenient. The phase composition, microstructure, Vickers hardness, thermal expansion coefficients, and chemical compatibility with $\mathrm{Al}_{2} \mathrm{O}_{3}$ are investigated. The high hardness, better phase stability, and good chemical compatibility with $\mathrm{Al}_{2} \mathrm{O}_{3}$ indicate that these new types of HECs are promising as high-performance TBC materials.

\section{Experimental}

$\mathrm{HE} \mathrm{RE} \mathrm{TaO}_{7}, \mathrm{RE}_{3} \mathrm{NbO}_{7}$, and $\mathrm{RE}_{3}\left(\mathrm{Nb}_{1 / 2} \mathrm{Ta}_{1 / 2}\right) \mathrm{O}_{7}$ powders were synthesized by the solid-state reaction method. Rare-earth oxides, tantalum oxide, and niobium oxide

Table 1 Ion radius and radius difference of the selecting REs for the design of $\mathrm{HE} \mathrm{RE}_{3} \mathrm{TaO}_{7}, \mathrm{RE}_{3} \mathrm{NbO}_{7}$, and $R_{3}\left(\mathrm{Nb}_{1 / 2} \mathrm{Ta}_{1 / 2}\right) \mathrm{O}_{7}$ (the data are obtained from the database of Materials studio program. (C) Accelrys Inc., San Diego, USA, 2014)

\begin{tabular}{ccc}
\hline $\mathrm{RE}$ & Ion radius $(\AA)$ & Radius difference $(\%)$ \\
\hline $\mathrm{Sm}$ & 0.96 & 12 \\
$\mathrm{Eu}$ & 0.95 & 10 \\
$\mathrm{Y}$ & 0.90 & 5 \\
$\mathrm{Er}$ & 0.89 & 3 \\
$\mathrm{Yb}$ & 0.87 & 1 \\
$\mathrm{Lu}$ & 0.86 & 0 \\
\hline
\end{tabular}


powders (99.9\% purity; HWRK Chem. Co., Ltd., Beijing, China) were mixed in the stoichiometric ratio of required $\mathrm{HE}$ compounds. In particular, the molar ratio of raw materials is $\mathrm{Y}_{2} \mathrm{O}_{3}: \mathrm{Yb}_{2} \mathrm{O}_{3}: \mathrm{Er}_{2} \mathrm{O}_{3}: \mathrm{Ta}_{2} \mathrm{O}_{3}=$ $1: 1: 1: 1$ for $\left(\mathrm{Y}_{1 / 3} \mathrm{Yb}_{1 / 3} \mathrm{Er}_{1 / 3}\right)_{3} \mathrm{TaO}_{7}, \mathrm{Y}_{2} \mathrm{O}_{3}: \mathrm{Yb}_{2} \mathrm{O}_{3}$ : $\mathrm{Er}_{2} \mathrm{O}_{3}: \mathrm{Nb}_{2} \mathrm{O}_{3}=1: 1: 1: 1$ for $\left(\mathrm{Y}_{1 / 3} \mathrm{Yb}_{1 / 3} \mathrm{Er}_{1 / 3}\right)_{3} \mathrm{NbO}_{7}$, and $\mathrm{Sm}_{2} \mathrm{O}_{3}: \mathrm{Eu}_{2} \mathrm{O}_{3}: \mathrm{Y}_{2} \mathrm{O}_{3}: \mathrm{Yb}_{2} \mathrm{O}_{3}: \mathrm{Lu}_{2} \mathrm{O}_{3}: \mathrm{Er}_{2} \mathrm{O}_{3}: \mathrm{Ta}_{2} \mathrm{O}_{3}$ : $\mathrm{Nb}_{2} \mathrm{O}_{3}=1: 1: 1: 1: 1: 1: 1: 1$ for $\left(\mathrm{Sm}_{1 / 6} \mathrm{Eu}_{1 / 6} \mathrm{Y}_{1 / 6} \mathrm{Yb}_{1 / 6}\right.$ $\left.\mathrm{Lu}_{1 / 6} \mathrm{Er}_{1 / 6}\right)_{3}\left(\mathrm{Nb}_{1 / 2} \mathrm{Ta}_{1 / 2}\right) \mathrm{O}_{7}$, respectively. After that, the mixed powders were ball-milled in ethyl alcohol with agate balls for $8 \mathrm{~h}$. Then the obtained mixed slurry was dried at $70{ }^{\circ} \mathrm{C}$ for $12 \mathrm{~h}$ and ground by an agate mortar to break the agglomeration. The obtained powders were compacted under a uniaxial pressure of $40 \mathrm{MPa}$ to make green bodies and then heated at $1450{ }^{\circ} \mathrm{C}$ for $2 \mathrm{~h}$. Finally, the as-heated compacts were broken and ball-milled for $12 \mathrm{~h}$ before drying in a vacuum oven at room temperature. The final products were screened by a 300-mesh sieve to filter out the coarse particles. For comparison, the single-principal-component $\mathrm{Y}_{3} \mathrm{TaO}_{7}$ and $\mathrm{Y}_{3} \mathrm{NbO}_{7}$ powders were also synthesized in the same experimental conditions.

The phase composition of as-synthesized powders was analyzed by an X-ray diffractometer (XRD, D8 Advanced, Bruker, Germany) using $\mathrm{Cu} \mathrm{K} \alpha$ radiation $(\lambda=1.5406 \AA)$ with a step size of $0.02^{\circ}$ at a scanning rate of $2\left(^{\circ}\right) / \mathrm{min}$. The lattice parameters of $\mathrm{HE} \mathrm{RE}_{3} \mathrm{TaO}_{7}$, $\mathrm{RE}_{3} \mathrm{NbO}_{7}$, and $\mathrm{RE}_{3}\left(\mathrm{Nb}_{1 / 2} \mathrm{Ta}_{1 / 2}\right) \mathrm{O}_{7}$ were refined by the Rietveld method (TOPAS, Bruker Corp., Karlsruhe, Germany).

Dense $\mathrm{HE} \mathrm{RE} \mathrm{RaO}_{7}, \mathrm{RE}_{3} \mathrm{NbO}_{7}$, and $\mathrm{RE}_{3}\left(\mathrm{Nb}_{1 / 2} \mathrm{Ta}_{1 / 2}\right) \mathrm{O}_{7}$ bulks were prepared by using a spark plasma sintering (SPS) apparatus (SPS-20T-6-IV, Shanghai Chenhua Science and Technology Co., Ltd., China) at $1650{ }^{\circ} \mathrm{C}$ for $4 \mathrm{~min}$ under a pressure of $40 \mathrm{MPa}$. Details of the preparation process were reported in our previous studies [34,36]. After sintering, the surfaces of as-sintered compacts were ground by diamond to remove the carburized layer. The density of as-sintered compacts was measured by Archimede's method. The phase composition of bulk compacts was analyzed by XRD. The microstructure and element distribution of bulk samples were investigated by a scanning electron microscope (SEM, Apollo300, CamScan, Cambridge, UK) with the attached energy dispersive X-ray spectroscopic (EDS) system (EDS Inca X-Max 80T, Oxford, UK). Before SEM observation, the samples were polished by \#2000 $\mathrm{SiC}$ sand paper and thermally etched at $1400{ }^{\circ} \mathrm{C}$ for $2 \mathrm{~h}$ to make the grain boundary clear.

Vickers hardness measurement was performed by a micro-hardness tester (HXD-1000TMC/LCD, Shanghai Taiming, China) at a load of $9.8 \mathrm{~N}$ with a dwell time of $15 \mathrm{~s}$. The linear thermal expansion coefficients were measured by an optical dilatometer (Misura ODHT 1600-50, Expert System Solutions, Italy) from room temperature to $1200{ }^{\circ} \mathrm{C}$ using the samples with a dimension of $3 \mathrm{~mm} \times 4 \mathrm{~mm} \times 15 \mathrm{~mm}$. Before the test, the samples were polished by \#2000 $\mathrm{SiC}$ sand paper and then chamfered at one end of the length. The length change of the samples $(\Delta L)$ with temperature $(T)$ was recorded and the thermal expansion coefficient $(\alpha)$ was calculated by Eq. (1):

$$
\alpha=\frac{\Delta L}{L_{0}\left(T-T_{0}\right)}
$$

where $L_{0}$ is the length of the sample at room temperature and $T_{0}$ is room temperature.

Good chemical compatibility with thermally grown $\mathrm{Al}_{2} \mathrm{O}_{3}$ (TGO) is critical for TBC materials. In order to investigate the chemical compatibility between $\mathrm{HE}$ $\mathrm{RE}_{3} \mathrm{TaO}_{7} / \mathrm{RE}_{3} \mathrm{NbO}_{7} / \mathrm{RE}_{3}\left(\mathrm{Nb}_{1 / 2} \mathrm{Ta}_{1 / 2}\right) \mathrm{O}_{7}$ and $\mathrm{Al}_{2} \mathrm{O}_{3}$, the as-synthesized $\mathrm{HE}$ powders were mixed with $\alpha-\mathrm{Al}_{2} \mathrm{O}_{3}$ powders (99.9\% purity; HWRK Chem. Co., Ltd., Beijing, China) in a mass ratio of $1: 1$ by ball-milling, and then annealed at different temperatures for $2 \mathrm{~h}$. For comparison, the chemical compatibility between $\mathrm{Y}_{3} \mathrm{TaO}_{7}$, $\mathrm{Y}_{3} \mathrm{NbO}_{7}$, and $\alpha-\mathrm{Al}_{2} \mathrm{O}_{3}$ was also investigated by the same method. The phase composition of the annealed products was investigated by XRD.

\section{Results and discussion}

\section{1 Phase composition and microstructure}

Figure 1 shows the XRD patterns of the as-synthesized $\mathrm{Y}_{3} \mathrm{TaO}_{7}, \mathrm{Y}_{3} \mathrm{NbO}_{7}$, and $\mathrm{HE} \mathrm{RE}_{3} \mathrm{TaO}_{7}, \mathrm{RE}_{3} \mathrm{NbO}_{7}$, and $\mathrm{RE}_{3}\left(\mathrm{Nb}_{1 / 2} \mathrm{Ta}_{1 / 2}\right) \mathrm{O}_{7}$ powders. It can be seen that all the as-synthesized powders are phase-pure. The crystal structures of $\left(\mathrm{Y}_{1 / 3} \mathrm{Yb}_{1 / 3} \mathrm{Er}_{1 / 3}\right)_{3} \mathrm{TaO}_{7},\left(\mathrm{Y}_{1 / 3} \mathrm{Yb}_{1 / 3} \mathrm{Er}_{1 / 3}\right)_{3} \mathrm{NbO}_{7}$, and $\left(\mathrm{Sm}_{1 / 6} \mathrm{Eu}_{1 / 6} \mathrm{Y}_{1 / 6} \mathrm{Yb}_{1 / 6} \mathrm{Lu}_{1 / 6} \mathrm{Er}_{1 / 6}\right)_{3}\left(\mathrm{Nb}_{1 / 2} \mathrm{Ta}_{1 / 2}\right) \mathrm{O}_{7}$ are defective fluorite despite that $\mathrm{Y}_{3} \mathrm{TaO}_{7}$ exhibits an orthorhombic structure. Interestingly, the intensities of the diffraction peaks from all reflections of $\left(\mathrm{Sm}_{1 / 6} \mathrm{Eu}_{1 / 6} \mathrm{Y}_{1 / 6} \mathrm{Yb}_{1 / 6} \mathrm{Lu}_{1 / 6} \mathrm{Er}_{1 / 6}\right)_{3}\left(\mathrm{Nb}_{1 / 2} \mathrm{Ta}_{1 / 2}\right) \mathrm{O}_{7}$ are significantly lower than those of the others. In addition, the widths of the peaks of $\left(\mathrm{Sm}_{1 / 6} \mathrm{Eu}_{1 / 6} \mathrm{Y}_{1 / 6} \mathrm{Yb}_{1 / 6} \mathrm{Lu}_{1 / 6} \mathrm{Er}_{1 / 6}\right)_{3}$ $\left(\mathrm{Nb}_{1 / 2} \mathrm{Ta}_{1 / 2}\right) \mathrm{O}_{7}$ are broadened. This is one of the main 
characteristics of high entropy materials and can be explained by the intrinsic lattice distortion caused by the addition of multi-principal elements with different atomic sizes, which leads to the increase of the atomic plane roughness and the decrease of the diffraction peak intensity [37]. Based on the XRD patterns in Fig. 1, the lattice parameters of $\mathrm{HE} \mathrm{RE}_{3} \mathrm{TaO}_{7}, \mathrm{RE}_{3} \mathrm{NbO}_{7}$, and $\mathrm{RE}_{3}\left(\mathrm{Nb}_{1 / 2} \mathrm{Ta}_{1 / 2}\right) \mathrm{O}_{7}$ were refined and their theoretical densities were calculated, which are depicted in Table 2. The refined lattice parameter of $\left(\mathrm{Y}_{1 / 3} \mathrm{Yb}_{1 / 3} \mathrm{Er}_{1 / 3}\right)_{3} \mathrm{NbO}_{7}$ is close to that of $\left(\mathrm{Y}_{1 / 3} \mathrm{Yb}_{1 / 3} \mathrm{Er}_{1 / 3}\right)_{3} \mathrm{TaO}_{7}$. However, due to

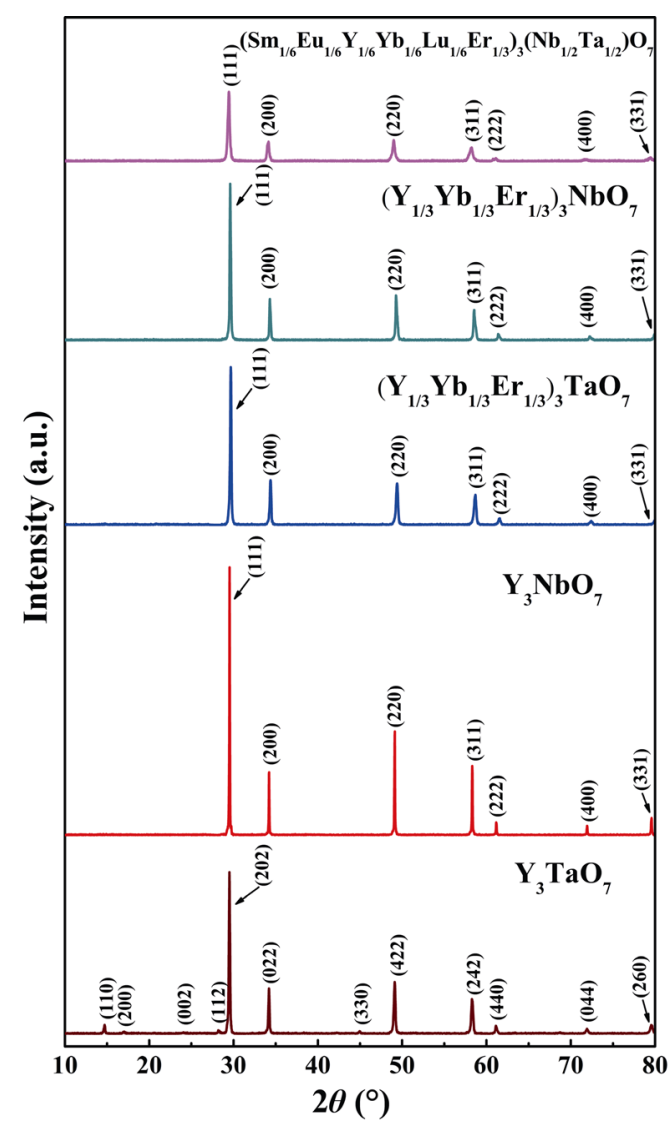

Fig. $1 \mathrm{XRD}$ patterns of the as-synthesized $\mathrm{Y}_{3} \mathrm{TaO}_{7}$, $\mathrm{Y}_{3} \mathrm{NbO}_{7}$, and $\mathrm{HE} \mathrm{RE} \mathrm{TaO}_{7}, \mathrm{RE}_{3} \mathrm{NbO}_{7}$, and $\mathrm{RE}_{3}\left(\mathrm{Nb}_{1 / 2} \mathrm{Ta}_{1 / 2}\right) \mathrm{O}_{7}$ powders.

Table 2 Refined lattice parameters of $\mathrm{HE} \mathrm{RE}_{3} \mathrm{TaO}_{7}$, $\mathrm{RE}_{3} \mathrm{NbO}_{7}$, and $\mathrm{RE}_{3}\left(\mathrm{Nb}_{1 / 2} \mathrm{Ta}_{1 / 2}\right) \mathrm{O}_{7}$ together with the calculated theoretical densities $\left(d_{\text {theo. }}\right)$ and the experimental measured densities $\left(d_{\text {exp. }}\right)$

\begin{tabular}{lccc}
\hline \multicolumn{1}{c}{ Space group } & \multicolumn{3}{c}{$F m \overline{3} m$} \\
\hline Composition & $a(\AA)$ & $\begin{array}{c}d_{\text {theo. }} \\
\left(\mathrm{g} / \mathrm{cm}^{3}\right)\end{array}$ & $\begin{array}{c}d_{\text {exp. }} \\
\left(\mathrm{g} / \mathrm{cm}^{3}\right)\end{array}$ \\
\hline$\left(\mathrm{Y}_{1 / 3} \mathrm{Yb}_{1 / 3} \mathrm{Er}_{1 / 3}\right)_{3} \mathrm{TaO}_{7}$ & 5.219 & 8.44 & 8.39 \\
$\left(\mathrm{Y}_{1 / 3} \mathrm{Yb}_{1 / 3} \mathrm{Er}_{1 / 3}\right)_{3} \mathrm{NbO}_{7}$ & 5.222 & 7.39 & 7.34 \\
$\left(\mathrm{Sm}_{1 / 6} \mathrm{Eu}_{1 / 6} \mathrm{Y}_{1 / 6} \mathrm{Yb}_{1 / 6} \mathrm{Lu}_{1 / 6} \mathrm{Er}_{1 / 6}\right)_{3}\left(\mathrm{Nb}_{1 / 2} \mathrm{Ta}_{1 / 2}\right) \mathrm{O}_{7}$ & 5.261 & 8.01 & 7.90 \\
\hline
\end{tabular}

the addition of more multi-principal elements with different sizes, $\left(\mathrm{Sm}_{1 / 6} \mathrm{Eu}_{1 / 6} \mathrm{Y}_{1 / 6} \mathrm{Yb}_{1 / 6} \mathrm{Lu}_{1 / 6} \mathrm{Er}_{1 / 6}\right)_{3}\left(\mathrm{Nb}_{1 / 2} \mathrm{Ta}_{1 / 2}\right) \mathrm{O}_{7}$ exhibits severer lattice distortion and possesses a larger lattice parameter. Correspondingly, the theoretical densities of three $\mathrm{HE} \mathrm{RE} \mathrm{TaO}_{7}, \mathrm{RE}_{3} \mathrm{NbO}_{7}$, and $\mathrm{RE}_{3}\left(\mathrm{Nb}_{1 / 2} \mathrm{Ta}_{1 / 2}\right) \mathrm{O}_{7}$ were calculated (Table 2).

In order to investigate the mechanical and thermal properties of $\mathrm{HE} \mathrm{RE}_{3} \mathrm{TaO}_{7}, \mathrm{RE}_{3} \mathrm{NbO}_{7}$, and $\mathrm{RE}_{3}\left(\mathrm{Nb}_{1 / 2} \mathrm{Ta}_{1 / 2}\right) \mathrm{O}_{7}$, it is essential to prepare dense bulk compacts. Figure 2 exhibits the XRD patterns of the bulk $\mathrm{HE} \mathrm{RE}_{3} \mathrm{TaO}_{7}, \mathrm{RE}_{3} \mathrm{NbO}_{7}$, and $\mathrm{RE}_{3}\left(\mathrm{Nb}_{1 / 2} \mathrm{Ta}_{1 / 2}\right) \mathrm{O}_{7}$ compacts prepared by SPS method. Clearly, the phase compositions of all three compacts are unchanged and no new phase can be detected, indicating that the $\mathrm{HE}$ $\mathrm{RE}_{3} \mathrm{TaO}_{7}, \mathrm{RE}_{3} \mathrm{NbO}_{7}$, and $\mathrm{RE}_{3}\left(\mathrm{Nb}_{1 / 2} \mathrm{Ta}_{1 / 2}\right) \mathrm{O}_{7}$ have good thermal stability. The SEM images of the bulk HE $\mathrm{RE}_{3} \mathrm{TaO}_{7}, \mathrm{RE}_{3} \mathrm{NbO}_{7}$, and $\mathrm{RE}_{3}\left(\mathrm{Nb}_{1 / 2} \mathrm{Ta}_{1 / 2}\right) \mathrm{O}_{7}$ compacts after thermal etching at $1400{ }^{\circ} \mathrm{C}$ for $2 \mathrm{~h}$ and the corresponding EDS mappings of the containing multi-principal metal elements are shown in Fig. 3. No pores and cracks can be observed at the surface of all three bulk materials, indicating that the as-sintered bulk compacts are near fully dense. The densities of $\left(\mathrm{Y}_{1 / 3} \mathrm{Yb}_{1 / 3} \mathrm{Er}_{1 / 3}\right)_{3} \mathrm{TaO}_{7},\left(\mathrm{Y}_{1 / 3} \mathrm{Yb}_{1 / 3} \mathrm{Er}_{1 / 3}\right)_{3} \mathrm{NbO}_{7}$, and $\left(\mathrm{Sm}_{1 / 6} \mathrm{Eu}_{1 / 6} \mathrm{Y}_{1 / 6} \mathrm{Yb}_{1 / 6} \mathrm{Lu}_{1 / 6} \mathrm{Er}_{1 / 6}\right)_{3}\left(\mathrm{Nb}_{1 / 2} \mathrm{Ta}_{1 / 2}\right) \mathrm{O}_{7}$ measured by Archimede's method are depicted in Table 2. Clearly, the relative densities of all the samples are about $99 \%$. Moreover, all the bulk compacts present equiaxed grains,

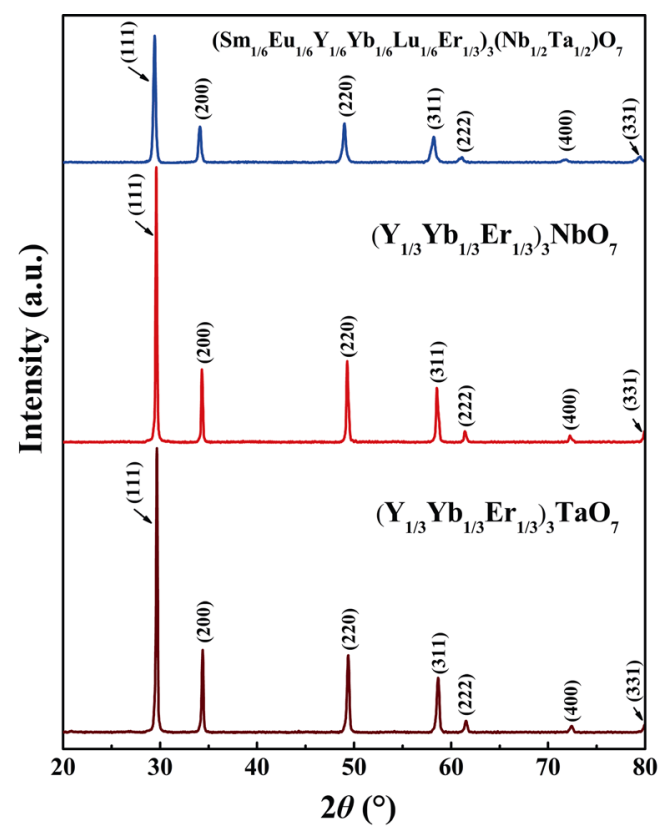

Fig. 2 XRD patterns of the bulk $\mathrm{HE} \mathrm{RE}_{3} \mathrm{TaO}_{7}, \mathrm{RE}_{3} \mathrm{NbO}_{7}$, and $\mathrm{RE}_{3}\left(\mathrm{Nb}_{1 / 2} \mathrm{Ta}_{1 / 2}\right) \mathrm{O}_{7}$ compacts prepared by SPS method. 


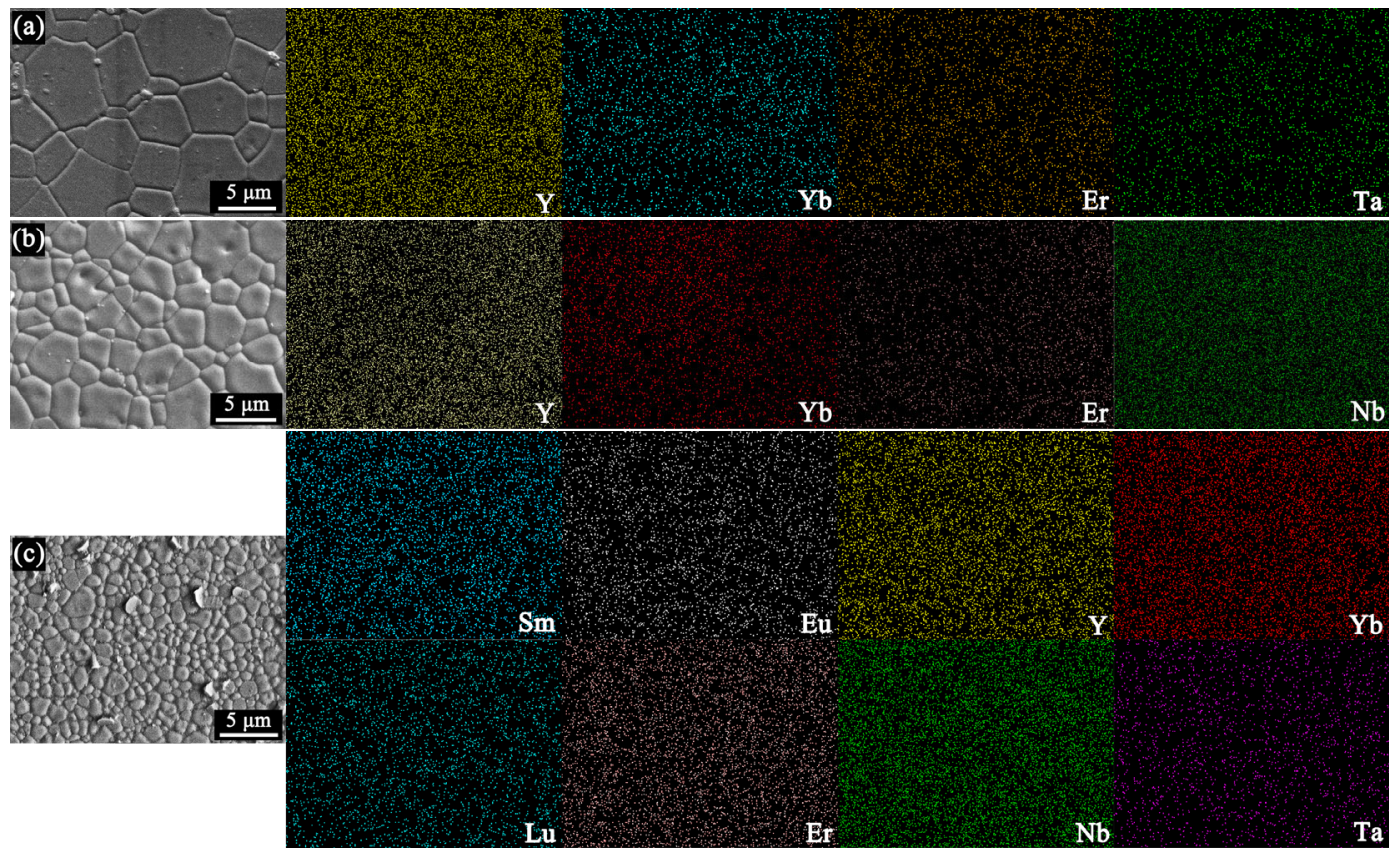

Fig. 3 SEM images and the corresponding EDS mappings of the containing multi-principal metal elements of the bulk HE $\mathrm{RE}_{3} \mathrm{TaO}_{7}, \mathrm{RE}_{3} \mathrm{NbO}_{7}$, and $\mathrm{RE}_{3}\left(\mathrm{Nb}_{1 / 2} \mathrm{Ta}_{1 / 2}\right) \mathrm{O}_{7}$ compacts after thermal etching at $1400{ }^{\circ} \mathrm{C}$ for $2 \mathrm{~h}:$ (a) $\left(\mathrm{Y}_{1 / 3} \mathrm{Yb}_{1 / 3} \mathrm{Er}_{1 / 3}\right)_{3} \mathrm{TaO}_{7},(\mathrm{~b})$ $\left(\mathrm{Y}_{1 / 3} \mathrm{Yb}_{1 / 3} \mathrm{Er}_{1 / 3}\right)_{3} \mathrm{NbO}_{7}$, and (c) $\left(\mathrm{Sm}_{1 / 6} \mathrm{Eu}_{1 / 6} \mathrm{Y}_{1 / 6} \mathrm{Yb}_{1 / 6} \mathrm{Lu}_{1 / 6} \mathrm{Er}_{1 / 6}\right)_{3}\left(\mathrm{Nb}_{1 / 2} \mathrm{Ta}_{1 / 2}\right) \mathrm{O}_{7}$.

but the average grain size of $\left(\mathrm{Sm}_{1 / 6} \mathrm{Eu}_{1 / 6} \mathrm{Y}_{1 / 6} \mathrm{Yb}_{1 / 6} \mathrm{Lu}_{1 / 6} \mathrm{Er}_{1 / 6}\right)_{3}$ $\left(\mathrm{Nb}_{1 / 2} \mathrm{Ta}_{1 / 2}\right) \mathrm{O}_{7}$ is evidently smaller than those of $\left(\mathrm{Y}_{1 / 3} \mathrm{Yb}_{1 / 3} \mathrm{Er}_{1 / 3}\right)_{3} \mathrm{TaO}_{7}$ and $\left(\mathrm{Y}_{1 / 3} \mathrm{Yb}_{1 / 3} \mathrm{Er}_{1 / 3}\right)_{3} \mathrm{NbO}_{7}$ (Table $3)$. The grain size difference of three near fully dense materials can be explained by the sluggish diffusion effect of high entropy materials. The lattice distortion induced by addition of multi-principal elements hinders the atomic movement and effective diffusion of the atoms and thus makes the grain growth rate slower [38]. The EDS mappings indicate that all the containing principal metal elements of three bulk materials are evenly distributed and thus the homogeneous solid solutions are formed.

\section{2 Vickers hardness}

During the service, the thermal barrier coatings usually suffer from the corrosion caused by the impact of foreign particles in the fluid. Thus, Vickers hardness of TBC materials is an important parameter and high Vickers hardness can retard the impact corrosion rate of TBC materials. Table 3 exhibits the Vickers hardness of HE $\mathrm{RE}_{3} \mathrm{TaO}_{7}, \mathrm{RE}_{3} \mathrm{NbO}_{7}$, and $\mathrm{RE}_{3}\left(\mathrm{Nb}_{1 / 2} \mathrm{Ta}_{1 / 2}\right) \mathrm{O}_{7}$ measured at a $9.8 \mathrm{~N}$ load and compared with the Vickers hardness of $\mathrm{RE}_{3} \mathrm{NbO}_{7}, \mathrm{RE}_{3} \mathrm{TaO}_{7}$, and $\mathrm{YSZ}$ [17,22-24].

Table 3 Vickers hardness and average grain size of $\mathrm{HE} \mathrm{RE}_{3} \mathrm{TaO}_{7}, \mathrm{RE}_{3} \mathrm{NbO}_{7}$, and $\mathrm{RE}_{3}\left(\mathrm{Nb}_{1 / 2} \mathrm{Ta}_{1 / 2}\right) \mathrm{O}_{7}$ measured at a $9.8 \mathrm{~N}$ load. The Vickers hardness of $\mathrm{RE}_{3} \mathrm{NbO}_{7}, \mathrm{RE}_{3} \mathrm{TaO}_{7}$, and $\mathrm{YSZ}$ are also included for comparison

\begin{tabular}{ccc}
\hline Composition & Vickers hardness $(\mathrm{GPa})$ & Average grain size $(\mu \mathrm{m})$ \\
\hline$\left(\mathrm{Y}_{1 / 3} \mathrm{Yb}_{1 / 3} \mathrm{Er}_{1 / 3}\right)_{3} \mathrm{TaO}_{7}$ & $11.6 \pm 0.3$ & 3.63 \\
$\left(\mathrm{Y}_{1 / 3} \mathrm{Yb}_{1 / 3} \mathrm{Er}_{1 / 3}\right)_{3} \mathrm{NbO}_{7}$ & $12.0 \pm 0.5$ & 2.64 \\
$\left(\mathrm{Sm}_{1 / 6} \mathrm{Eu}_{1 / 6} \mathrm{Y}_{1 / 6} \mathrm{Yb}_{1 / 6} \mathrm{Lu}_{1 / 6} \mathrm{Er}_{1 / 6}\right)_{3}\left(\mathrm{Nb}_{1 / 2} \mathrm{Ta}_{1 / 2}\right) \mathrm{O}_{7}$ & $10.9 \pm 0.2$ & 0.96 \\
$\mathrm{Y}_{3} \mathrm{NbO}_{7}$ & 8.76 & - \\
$\mathrm{Yb}_{3} \mathrm{NbO}_{7}$ & 9.88 & - \\
$\mathrm{Er}_{3} \mathrm{NbO}_{7}$ & 8.88 & - \\
$\mathrm{Sm}_{3} \mathrm{NbO}_{7}$ & 5.6 & - \\
$\mathrm{Eu}_{3} \mathrm{NbO}_{7}$ & 7.0 & - \\
$\mathrm{Yb}_{3} \mathrm{TaO}_{7}$ & 9.8 & - \\
$\mathrm{YSZ}$ & 13.5 & \\
\hline
\end{tabular}


Clearly, the Vickers hardness of $\left(\mathrm{Y}_{1 / 3} \mathrm{Yb}_{1 / 3} \mathrm{Er}_{1 / 3}\right)_{3} \mathrm{TaO}_{7}$, $\left(\mathrm{Y}_{1 / 3} \mathrm{Yb}_{1 / 3} \mathrm{Er}_{1 / 3}\right)_{3} \mathrm{NbO}_{7}$, and $\left(\mathrm{Sm}_{1 / 6} \mathrm{Eu}_{1 / 6} \mathrm{Y}_{1 / 6} \mathrm{Yb}_{1 / 6} \mathrm{Lu}_{1 / 6} \mathrm{Er}_{1 / 6}\right)_{3}$ $\left(\mathrm{Nb}_{1 / 2} \mathrm{Ta}_{1 / 2}\right) \mathrm{O}_{7}$ are close to that of $\mathrm{YSZ}$, but higher than those of $\mathrm{Y}_{3} \mathrm{NbO}_{7}, \mathrm{Yb}_{3} \mathrm{NbO}_{7}, \mathrm{Er}_{3} \mathrm{NbO}_{7}, \mathrm{Sm}_{3} \mathrm{NbO}_{7}$, $\mathrm{Eu}_{3} \mathrm{NbO}_{7}$, and $\mathrm{Yb}_{3} \mathrm{TaO}_{7}$. The relative high hardness indicates that $\mathrm{HE} \quad \mathrm{RE}_{3} \mathrm{TaO}_{7}, \mathrm{RE}_{3} \mathrm{NbO}_{7}$, and $\mathrm{RE}_{3}\left(\mathrm{Nb}_{1 / 2} \mathrm{Ta}_{1 / 2}\right) \mathrm{O}_{7}$ may possess good impact corrosion resistance, which is beneficial to their application as thermal barrier coating materials.

\section{3 Thermal expansion coefficient (CTE) and phase stability}

CTE is also a critical parameter to be taken into account. In order to diminish the thermal stress between TBCs and substrates, materials which have close CTE to that of the substrates are preferential for TBC applications. Figure 4 shows the linear CTEs of $\mathrm{HE} \mathrm{RE}_{3} \mathrm{TaO}_{7}$, $\mathrm{RE}_{3} \mathrm{NbO}_{7}$, and $\mathrm{RE}_{3}\left(\mathrm{Nb}_{1 / 2} \mathrm{Ta}_{1 / 2}\right) \mathrm{O}_{7}$ measured from room temperature to $1200{ }^{\circ} \mathrm{C}$. Based on Eq. (1), the linear CTEs of $\left(\mathrm{Y}_{1 / 3} \mathrm{Yb}_{1 / 3} \mathrm{Er}_{1 / 3}\right)_{3} \mathrm{TaO}_{7},\left(\mathrm{Y}_{1 / 3} \mathrm{Yb}_{1 / 3} \mathrm{Er}_{1 / 3}\right)_{3} \mathrm{NbO}_{7}$, and $\left(\mathrm{Sm}_{1 / 6} \mathrm{Eu}_{1 / 6} \mathrm{Y}_{1 / 6} \mathrm{Yb}_{1 / 6} \mathrm{Lu}_{1 / 6} \mathrm{Er}_{1 / 6}\right)_{3}\left(\mathrm{Nb}_{1 / 2} \mathrm{Ta}_{1 / 2}\right) \mathrm{O}_{7}$ from room temperature to $1200{ }^{\circ} \mathrm{C}$ are calculated to be $9.0 \times 10^{-6}, 10.8 \times 10^{-6}$, and $7.9 \times 10^{-6}{ }^{\circ} \mathrm{C}^{-1}$, respectively. It is intriguing that CTE of $\left(\mathrm{Sm}_{1 / 6} \mathrm{Eu}_{1 / 6} \mathrm{Y}_{1 / 6} \mathrm{Yb}_{1 / 6} \operatorname{Lu}_{1 / 6} \mathrm{Er}_{1 / 6}\right)_{3}$ $\left(\mathrm{Nb}_{1 / 2} \mathrm{Ta}_{1 / 2}\right) \mathrm{O}_{7}$ is much lower than those of $\left(\mathrm{Y}_{1 / 3} \mathrm{Yb}_{1 / 3} \mathrm{Er}_{1 / 3}\right)_{3} \mathrm{TaO}_{7}$ and $\left(\mathrm{Y}_{1 / 3} \mathrm{Yb}_{1 / 3} \mathrm{Er}_{1 / 3}\right)_{3} \mathrm{NbO}_{7}$. The result can be explained from two aspects. Firstly, the high entropy effect hinders the oscillation amplitude of constituting atoms by severe lattice distortion. Secondly, it is well known that the CTEs are related to the lattice energy. The average interatomic distance $\langle R\rangle$ is related to the atomic interaction potential energy $U(R)$ through Eq. (2) [39]:

$$
\langle R\rangle=\frac{\int_{-\infty}^{\infty} R \mathrm{e}^{-\frac{U(R)}{k_{\mathrm{b}} T}} \mathrm{~d} R}{\int_{-\infty}^{\infty} \mathrm{e}^{-\frac{U(R)}{k_{\mathrm{b}} T}} \mathrm{~d} R}
$$

where $k_{\mathrm{b}}$ is Boltzmann constant. In light of Eq. (2), materials with higher lattice energy usually exhibit lower CTEs. As reported in previous study of Chen et al. [23], the lattice energy of $\mathrm{RE}_{3} \mathrm{NbO}_{7}$ increases with the decreasing $\mathrm{RE}^{3+}$ ionic radius $\left(\mathrm{La}^{3+} \rightarrow \mathrm{Lu}^{3+}\right)$ due to the decrease of crystal structural order (ordered orthorhombic to defective fluorite). Thus the CTEs of $\mathrm{RE}_{3} \mathrm{NbO}_{7}$ increase with the decreasing $\mathrm{RE}^{3+}$ ionic radius. Since the ionic radius of $\mathrm{Sm}^{3+}$ and $\mathrm{Eu}^{3+}$ are larger than those of $\mathrm{Y}^{3+}, \mathrm{Yb}^{3+}$, and $\mathrm{Er}^{3+}$ (Table 1), the CTEs of the compounds containing $\mathrm{Sm}^{3+}$ and $\mathrm{Eu}^{3+}$

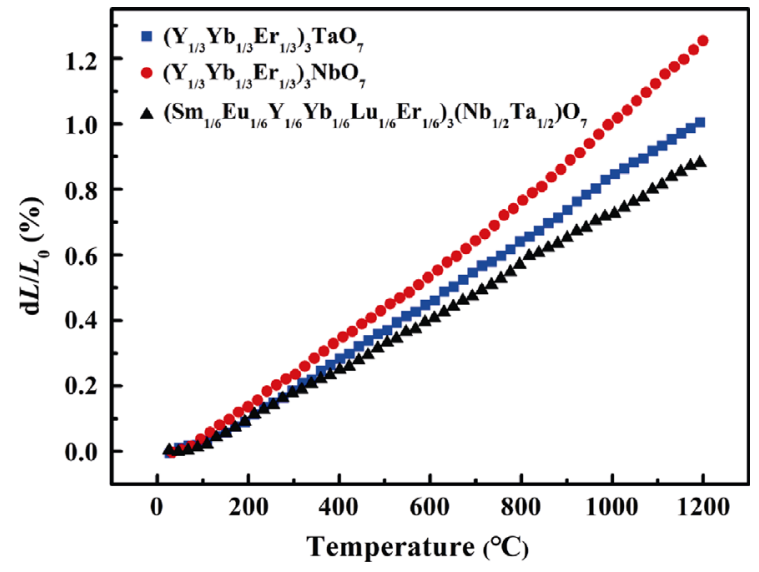

Fig. 4 Linear thermal expansion curves of $\mathrm{HE} \mathrm{RE}_{3} \mathrm{TaO}_{7}$, $\mathrm{RE}_{3} \mathrm{NbO}_{7}$, and $\mathrm{RE}_{3}\left(\mathrm{Nb}_{1 / 2} \mathrm{Ta}_{1 / 2}\right) \mathrm{O}_{7}$ measured from room temperature to $1200{ }^{\circ} \mathrm{C}$.

are smaller than those containing only $\mathrm{Y}^{3+}, \mathrm{Yb}^{3+}$, and $\mathrm{Er}^{3+}$. Thus the lower CTE of $\left(\operatorname{Sm}_{1 / 6} \operatorname{Eu}_{1 / 6} \mathrm{Y}_{1 / 6} \mathrm{Yb}_{1 / 6} \operatorname{Lu}_{1 / 6} \operatorname{Er}_{1 / 6}\right)_{3}$ $\left(\mathrm{Nb}_{1 / 2} \mathrm{Ta}_{1 / 2}\right) \mathrm{O}_{7}$ may be explained by the high entropy effect which hinders the oscillation amplitude of constitute atoms by severe lattice distortion and the high lattice energy due to the addition of the REs with large ionic radius. Furthermore, the thermal expansion curves of all the samples are nearly linear and no phase transformation with abrupt volume change occurs in the measured temperature range. It is noteworthy that $\mathrm{Sm}_{3} \mathrm{TaO}_{7}$ and $\mathrm{Sm}_{3} \mathrm{NbO}_{7}$ exhibit abrupt volume change at 942 and $817{ }^{\circ} \mathrm{C}$, respectively, due to the phase transition [22,25]. Nevertheless, although samarium is selected as a principal element to be added into the solid solution, the abrupt volume change does not occur when $\left(\mathrm{Sm}_{1 / 6} \mathrm{Eu}_{1 / 6} \mathrm{Y}_{1 / 6} \mathrm{Yb}_{1 / 6} \mathrm{Lu}_{1 / 6} \mathrm{Er}_{1 / 6}\right)_{3}\left(\mathrm{Nb}_{1 / 2} \mathrm{Ta}_{1 / 2}\right) \mathrm{O}_{7}$ was heated from room temperature to $1200{ }^{\circ} \mathrm{C}$, which indicates that the phase transition is suppressed and all the $\mathrm{HE} \mathrm{RE}_{3} \mathrm{TaO}_{7}, \mathrm{RE}_{3} \mathrm{NbO}_{7}$, and $\mathrm{RE}_{3}\left(\mathrm{Nb}_{1 / 2} \mathrm{Ta}_{1 / 2}\right) \mathrm{O}_{7}$ have good phase stability.

\section{4 Chemical compatibility with $\mathrm{Al}_{2} \mathrm{O}_{3}$}

When gas-turbine engines operate at high temperatures, the interconnected porosity of ceramic coatings always allows the ingress of oxygen from the engine environment to the bond-coat layer, which results in the oxidation of bond-coat layer and the formation of TGO layer between the bond-coat layer and the ceramic top-coat layer [1]. Thus, TBC materials are required to possess good chemical compatibility with TGO. To

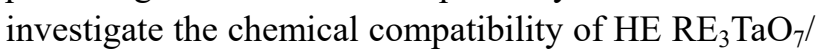
$\mathrm{RE}_{3} \mathrm{NbO}_{7} / \mathrm{RE}_{3}\left(\mathrm{Nb}_{1 / 2} \mathrm{Ta}_{1 / 2}\right) \mathrm{O}_{7}$ with TGO, powder mixtures of $\mathrm{HE} \mathrm{RE} \mathrm{TaO}_{7} / \mathrm{RE}_{3} \mathrm{NbO}_{7} / \mathrm{RE}_{3}\left(\mathrm{Nb}_{1 / 2} \mathrm{Ta}_{1 / 2}\right) \mathrm{O}_{7}$ and $\mathrm{Al}_{2} \mathrm{O}_{3}$ 
were heated to different temperatures for $2 \mathrm{~h}$. Figure 5 shows the XRD patterns of the mixed powders of $\mathrm{Y}_{3} \mathrm{TaO}_{7}, \mathrm{Y}_{3} \mathrm{NbO}_{7}, \mathrm{HE} \mathrm{RE}_{3} \mathrm{TaO}_{7}, \mathrm{HE} \mathrm{RE}_{3} \mathrm{NbO}_{7}, \mathrm{HE}$ $\mathrm{RE}_{3}\left(\mathrm{Nb}_{1 / 2} \mathrm{Ta}_{1 / 2}\right) \mathrm{O}_{7}$, and $\alpha-\mathrm{Al}_{2} \mathrm{O}_{3}$ after annealed at different temperatures for $2 \mathrm{~h}$. As shown in Fig. 5(a), only $\alpha-\mathrm{Al}_{2} \mathrm{O}_{3}, \mathrm{Y}_{3} \mathrm{TaO}_{7}, \mathrm{Y}_{3} \mathrm{NbO}_{7}$, and $\mathrm{HE} \mathrm{RE}_{3} \mathrm{TaO}_{7}, \mathrm{RE}_{3} \mathrm{NbO}_{7}$, $\mathrm{RE}_{3}\left(\mathrm{Nb}_{1 / 2} \mathrm{Ta}_{1 / 2}\right) \mathrm{O}_{7}$ phases can be detected when annealed at $1200{ }^{\circ} \mathrm{C}$, which indicates that both $\mathrm{Y}_{3} \mathrm{TaO}_{7}$ and $\mathrm{Y}_{3} \mathrm{NbO}_{7}$, as well as $\mathrm{HE} \mathrm{RE}_{3} \mathrm{TaO}_{7}, \mathrm{RE}_{3} \mathrm{NbO}_{7}, \mathrm{RE}_{3}$ $\left(\mathrm{Nb}_{1 / 2} \mathrm{Ta}_{1 / 2}\right) \mathrm{O}_{7} / \mathrm{Al}_{2} \mathrm{O}_{3}$ have good chemical compatibility with $\alpha-\mathrm{Al}_{2} \mathrm{O}_{3}$ at $1200{ }^{\circ} \mathrm{C}$. The above results are consistent with those of Yang et al. [22], who reported the good chemical compatibility of $\mathrm{RE}_{3} \mathrm{NbO}_{7}$ with $\mathrm{Al}_{2} \mathrm{O}_{3}$ up to $1200{ }^{\circ} \mathrm{C}$. When the temperature increases to $1250{ }^{\circ} \mathrm{C}$, no new phase can be detected from the mixed powders of $\mathrm{Y}_{3} \mathrm{TaO}_{7} / \mathrm{Al}_{2} \mathrm{O}_{3}, \mathrm{HE} \mathrm{RE}_{3} \mathrm{TaO}_{7} / \mathrm{Al}_{2} \mathrm{O}_{3}$, and $\mathrm{RE}_{3}\left(\mathrm{Nb}_{1 / 2} \mathrm{Ta}_{1 / 2}\right) \mathrm{O}_{7} / \mathrm{Al}_{2} \mathrm{O}_{3}$, which indicates that $\mathrm{Y}_{3} \mathrm{TaO}_{7}, \mathrm{HE} \mathrm{RE}_{3} \mathrm{TaO}_{7}$, and $\mathrm{RE}_{3}\left(\mathrm{Nb}_{1 / 2} \mathrm{Ta}_{1 / 2}\right) \mathrm{O}_{7}$ remain good chemical compatibility with $\alpha-\mathrm{Al}_{2} \mathrm{O}_{3}$ at $1250{ }^{\circ} \mathrm{C}$. However, $\mathrm{Y}_{3} \mathrm{NbO}_{7}$ and $\mathrm{HE} \mathrm{RE}_{3} \mathrm{NbO}_{7}$ start to react with $\alpha-\mathrm{Al}_{2} \mathrm{O}_{3}$ with the formation of $\mathrm{RE}_{3} \mathrm{Al}_{5} \mathrm{O}_{12}$ and $\mathrm{RENbO}_{4}$ (Fig. 5(b)). When annealed at $1300{ }^{\circ} \mathrm{C}$, all the samples react with $\mathrm{Al}_{2} \mathrm{O}_{3}$ and yield $\mathrm{RE}_{3} \mathrm{Al}_{5} \mathrm{O}_{12}, \mathrm{RETaO}_{4}$, $\mathrm{RENbO}_{4}$, and $\mathrm{RE}\left(\mathrm{Ta}_{1 / 2} \mathrm{Nb}_{1 / 2}\right) \mathrm{O}_{4}$ (Fig. 5(c)). Since the maximum temperature for TGO is usually lower than $1200{ }^{\circ} \mathrm{C}$, we can conclude that $\mathrm{HE} \mathrm{RE}_{3} \mathrm{TaO}_{7}, \mathrm{RE}_{3} \mathrm{NbO}_{7}$, and $\mathrm{RE}_{3}\left(\mathrm{Nb}_{1 / 2} \mathrm{Ta}_{1 / 2}\right) \mathrm{O}_{7}$ have good chemical compatibility with TGO. At higher operating temperatures, HE $\mathrm{RE}_{3} \mathrm{TaO}_{7}$ exhibits better chemical compatibility with TGO than $\mathrm{HE} \mathrm{RE}_{3} \mathrm{NbO}_{7}$.

\section{Conclusions}

In this study, novel $\mathrm{HE} \mathrm{RE}_{3} \mathrm{TaO}_{7}, \mathrm{RE}_{3} \mathrm{NbO}_{7}$, and $\mathrm{RE}_{3}\left(\mathrm{Nb}_{1 / 2} \mathrm{Ta}_{1 / 2}\right) \mathrm{O}_{7}$, i.e., $\left(\mathrm{Y}_{1 / 3} \mathrm{Yb}_{1 / 3} \mathrm{Er}_{1 / 3}\right)_{3} \mathrm{TaO}_{7}$, $\left(\mathrm{Y}_{1 / 3} \mathrm{Yb}_{1 / 3} \mathrm{Er}_{1 / 3}\right)_{3} \mathrm{NbO}_{7}$, and $\left(\mathrm{Sm}_{1 / 6} \mathrm{Eu}_{1 / 6} \mathrm{Y}_{1 / 6} \mathrm{Yb}_{1 / 6} \mathrm{Lu}_{1 / 6} \mathrm{Er}_{1 / 6}\right)_{3}$ $\left(\mathrm{Nb}_{1 / 2} \mathrm{Ta}_{1 / 2}\right) \mathrm{O}_{7}$ are designed and synthesized successfully. The combination of XRD, SEM, and EDS analysis indicates that the as-synthesized $\mathrm{HE} \mathrm{RE} \mathrm{RaO}_{7}, \mathrm{RE}_{3} \mathrm{NbO}_{7}$, and $\mathrm{RE}_{3}\left(\mathrm{Nb}_{1 / 2} \mathrm{Ta}_{1 / 2}\right) \mathrm{O}_{7}$ are phase-pure with homogeneous distribution of metal elements. The Vickers hardness of $\mathrm{HE} \mathrm{RE} \mathrm{TaO}_{7}, \mathrm{RE}_{3} \mathrm{NbO}_{7}$, and $\mathrm{RE}_{3}\left(\mathrm{Nb}_{1 / 2} \mathrm{Ta}_{1 / 2}\right) \mathrm{O}_{7}$ are in the range of 10.9-12.0 GPa, which are close to that of YSZ but significantly higher than those of singleprincipal-component $\mathrm{RE}_{3} \mathrm{TaO}_{7}$ and $\mathrm{RE}_{3} \mathrm{NbO}_{7}$. The thermal expansion coefficients of $\left(\mathrm{Y}_{1 / 3} \mathrm{Yb}_{1 / 3} \mathrm{Er}_{1 / 3}\right)_{3} \mathrm{TaO}_{7}$, $\left(\mathrm{Y}_{1 / 3} \mathrm{Yb}_{1 / 3} \mathrm{Er}_{1 / 3}\right)_{3} \mathrm{NbO}_{7}$, and $\left(\mathrm{Sm}_{1 / 6} \mathrm{Eu}_{1 / 6} \mathrm{Y}_{1 / 6} \mathrm{Yb}_{1 / 6} \mathrm{Lu}_{1 / 6} \mathrm{Er}_{1 / 6}\right)_{3}$ $\left(\mathrm{Nb}_{1 / 2} \mathrm{Ta}_{1 / 2}\right) \mathrm{O}_{7}$ from room temperature to $1200{ }^{\circ} \mathrm{C}$ are $9.0 \times 10^{-6}, 10.8 \times 10^{-6}$, and $7.9 \times 10^{-6}{ }^{\circ} \mathrm{C}^{-1}$, respectively. All the as-synthesized $\mathrm{HE} \mathrm{RE}_{3} \mathrm{TaO}_{7}, \mathrm{RE}_{3} \mathrm{NbO}_{7}$, and $\mathrm{RE}_{3}\left(\mathrm{Nb}_{1 / 2} \mathrm{Ta}_{1 / 2}\right) \mathrm{O}_{7}$ exhibit good phase stability at least up to $1200{ }^{\circ} \mathrm{C}$. $\mathrm{HE} \mathrm{RE}_{3} \mathrm{TaO}_{7}$ and $\mathrm{RE}_{3}\left(\mathrm{Nb}_{1 / 2} \mathrm{Ta}_{1 / 2}\right) \mathrm{O}_{7}$ show better chemical compatibility (without reaction
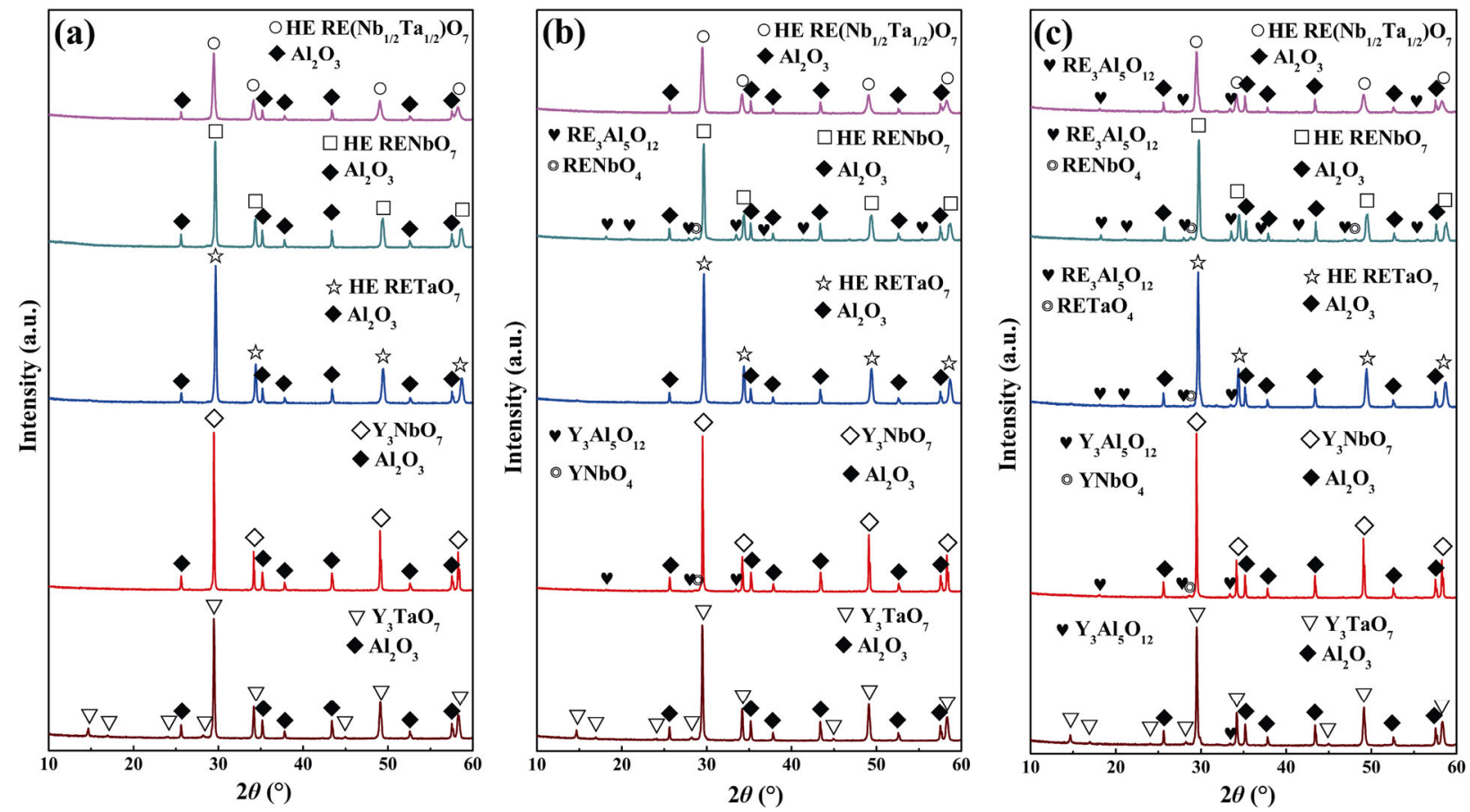

Fig. 5 XRD patterns of the mixed powders of $\mathrm{Y}_{3} \mathrm{TaO}_{7}, \mathrm{Y}_{3} \mathrm{NbO}_{7}, \mathrm{HE} \mathrm{RE}_{3} \mathrm{TaO}_{7}, \mathrm{HE} \mathrm{RE}_{3} \mathrm{NbO}_{7}, \mathrm{HE} \mathrm{RE}_{3}\left(\mathrm{Nb}_{1 / 2} \mathrm{Ta}_{1 / 2}\right) \mathrm{O}_{7}$, and $\alpha-\mathrm{Al}_{2} \mathrm{O}_{3}$ after annealing at different temperatures for $2 \mathrm{~h}$ : (a) $1200{ }^{\circ} \mathrm{C}$, (b) $1250{ }^{\circ} \mathrm{C}$, and (c) $1300{ }^{\circ} \mathrm{C}$. 
up to $1250{ }^{\circ} \mathrm{C}$ ) with TGO than that of $\mathrm{HE} \mathrm{RE}_{3} \mathrm{NbO}_{7}$ (without reaction up to $1200{ }^{\circ} \mathrm{C}$ ). The combination of high Vickers hardness, good phase stability, and good chemical compatibility with TGO indicates that HE $\mathrm{RE}_{3} \mathrm{TaO}_{7}, \mathrm{RE}_{3} \mathrm{NbO}_{7}$, and $\mathrm{RE}_{3}\left(\mathrm{Nb}_{1 / 2} \mathrm{Ta}_{1 / 2}\right) \mathrm{O}_{7}$ are suitable for applications as promising TBC materials.

\section{Acknowledgements}

This study was financially supported by the National Natural Science Foundation of China (Nos. 51672064 and 51972089).

\section{References}

[1] Padture NP. Thermal barrier coatings for gas-turbine engine applications. Science 2002, 296: 280-284.

[2] Evans AG, Mumm DR, Hutchinson JW, et al. Mechanisms controlling the durability of thermal barrier coatings. Prog Mater Sci 2001, 46: 505-553.

[3] Miller RA. Current status of thermal barrier coatings-An overview. Surf Coat Technol 1987, 30: 1-11.

[4] Meier SM, Gupta DK, Sheffler KD. Ceramic thermal barrier coatings for commercial gas turbine engines. JOM 1991, 43: 50-53.

[5] Clarke DR, Oechsner M, Padture NP. Thermal-barrier coatings for more efficient gas-turbine engines. MRS Bull 2012, 37: 891-898.

[6] Liu B, Liu YC, Zhu CH, et al. Advances on strategies for searching for next generation thermal barrier coating materials. J Mater Sci Technol 2019, 35: 833-851.

[7] Cao XQ, Vassen R, Stoever D. Ceramic materials for thermal barrier coatings. J Eur Ceram Soc 2004, 24: 1-10.

[8] Cernuschi F, Bianchi $\mathrm{P}$, Leoni $\mathrm{M}$, et al. Thermal diffusivity/microstructure relationship in Y-PSZ thermal barrier coatings. J Therm Spray Technol 1999, 8: 102-109.

[9] Vassen R, Tietz F, Kerkhoff G, et al. New materials for advanced thermal barrier coatings. In Proceedings of the 6th Liége Conference on Materials for Advanced Power Engineering. Liége, Belgium: Universite de Liége press, 1998: 1635.

[10] Wallace JS, Ilavsky J. Elastic modulus measurements in plasma sprayed deposits. J Therm Spray Technol 1998, 7: 521-526.

[11] Ren XR, Pan W. Mechanical properties of high-temperaturedegraded yttria-stabilized zirconia. Acta Mater 2014, 69: 397-406.

[12] Slifka AJ, Filla BJ, Phelps JM, et al. Thermal conductivity of a zirconia thermal barrier coating. $J$ Therm Spray Tech 1998, 7: 43-46.

[13] Brandon JR, Taylor R. Phase stability of zirconia-based thermal barrier coatings part I. Zirconia-yttria alloys. Surf Coat Technol 1991, 46: 75-90.
[14] Cao XQ, Li JY, Zhong XH, et al. $\mathrm{La}_{2}\left(\mathrm{Zr}_{0.7} \mathrm{Ce}_{0.3}\right)_{2} \mathrm{O}_{7}-\mathrm{A}$ new oxide ceramic material with high sintering-resistance. Mater Lett 2008, 62: 2667-2669.

[15] Vassen R, Cao XQ, Tietz F, et al. Zirconates as new materials for thermal barrier coatings. J Am Ceram Soc 2004, 83: 2023-2028.

[16] Yang J, Qian X, Pan W, et al. Diffused lattice vibration and ultralow thermal conductivity in the binary $\mathrm{ln}-\mathrm{Nb}-\mathrm{O}$ oxide system. Adv Mater 2019: 1808222.

[17] Chen L, Hu MY, Wu FS, et al. Thermo-mechanical properties of fluorite $\mathrm{Yb}_{3} \mathrm{TaO}_{7}$ and $\mathrm{Yb}_{3} \mathrm{NbO}_{7}$ ceramics with glass-like thermal conductivity. J Alloys Compd 2019, 788: 1231-1239.

[18] Wakeshima M, Nishimine H, Hinatsu Y. Crystal structures and magnetic properties of rare earth tantalates $\mathrm{RE}_{3} \mathrm{TaO}_{7}(\mathrm{RE}=$ rare earths $) . J$ Phys: Condens Matter 2004, 16: $4103-4120$.

[19] Wakeshima M, Hinatsu Y. Magnetic properties and structural transitions of orthorhombic fluorite-related compounds $\mathrm{Ln}_{3} \mathrm{MO}_{7}$ (Ln=rare earths, $\mathrm{M}=$ transition metals). $J$ Solid State Chem 2010, 183: 2681-2688.

[20] Cai L, Nino JC. Structure and dielectric properties of $\mathrm{Ln}_{3} \mathrm{NbO}_{7}(\mathrm{Ln}=\mathrm{Nd}, \mathrm{Gd}, \mathrm{Dy}, \mathrm{Er}, \mathrm{Yb}$ and Y). J Eur Ceram Soc 2007, 27: 3971-3976.

[21] Doi Y, Harada Y, Hinatsu Y. Crystal structures and magnetic properties of fluorite-related oxides $\mathrm{Ln}_{3} \mathrm{NbO}_{7}$ (Ln=lanthanides). $J$ Solid State Chem 2009, 182: 709-715.

[22] Yang J, Pan W, Han Y, et al. Mechanical properties, oxygen barrier property, and chemical stability of $\mathrm{RE}_{3} \mathrm{NbO}_{7}$ or thermal barrier coating. J Am Ceram Soc 2020, 103: 2302-2308.

[23] Chen L, Wu P, Song P, et al. Potential thermal barrier coating materials: $\mathrm{RE}_{3} \mathrm{NbO}_{7}(\mathrm{RE}=\mathrm{La}, \mathrm{Nd}, \mathrm{Sm}, \mathrm{Eu}, \mathrm{Gd}, \mathrm{Dy})$ ceramics. J Am Ceram Soc 2018, 101: 4503-4508.

[24] Zhao M, Ren XR, Yang J, et al. Thermo-mechanical properties of $\mathrm{ThO}_{2}$-doped $\mathrm{Y}_{2} \mathrm{O}_{3}$ stabilized $\mathrm{ZrO}_{2}$ for thermal barrier coatings. Ceram Int 2016, 42: 501-508.

[25] Chen L, Wu P, Feng J. Optimization thermophysical properties of $\mathrm{TiO}_{2}$ alloying $\mathrm{Sm}_{3} \mathrm{TaO}_{7}$ ceramics as promising thermal barrier coatings. Int J Appl Ceram Technol 2019, 16: $230-242$.

[26] Rost CM, Sachet E, Borman T, et al. Entropy-stabilized oxides. Nat Commun 2015, 6: 8485.

[27] Chen KP, Pei XT, Tang L, et al. A five-component entropy-stabilized fluorite oxide. J Eur Ceram Soc 2018, 38: 4161-4164.

[28] Miracle DB, Senkov ON. A critical review of high entropy alloys and related concepts. Acta Mater 2017, 122: 448-511.

[29] Dong Y, Ren K, Lu YH, et al. High-entropy environmental barrier coating for the ceramic matrix composites. $J$ Eur Ceram Soc 2019, 39: 2574-2579.

[30] Yan XL, Constantin L, Lu YF, et al. $\left(\mathrm{Hf}_{0.2} \mathrm{Zr}_{0.2} \mathrm{Ta}_{0.2} \mathrm{Nb}_{0.2} \mathrm{Ti}_{0.2}\right) \mathrm{C}$ high-entropy ceramics with low thermal conductivity. $\mathrm{J} \mathrm{Am}$ Ceram Soc 2018, 101: 4486-4491.

[31] Chen H, Xiang HM, Dai FZ, et al. Porous high entropy 
$\left(\mathrm{Zr}_{0.2} \mathrm{Hf}_{0.2} \mathrm{Ti}_{0.2} \mathrm{Nb}_{0.2} \mathrm{Ta}_{0.2}\right) \mathrm{B}_{2}$ : A novel strategy towards making ultrahigh temperature ceramics thermal insulating. J Mater Sci Technol 2019, 35: 2404-2408.

[32] Chen H, Xiang HM, Dai FZ, et al. High porosity and low thermal conductivity high entropy $\left(\mathrm{Zr}_{0.2} \mathrm{Hf}_{0.2} \mathrm{Ti}_{0.2} \mathrm{Nb}_{0.2} \mathrm{Ta}_{0.2}\right) \mathrm{C}$. J Mater Sci Technol 2019, 35: 1700-1705.

[33] Zhao ZF, Xiang HM, Dai FZ, et al. (TiZrHf) $\mathrm{P}_{2} \mathrm{O}_{7}$ : An equimolar multicomponent or high entropy ceramic with good thermal stability and low thermal conductivity. $J$ Mater Sci Technol 2019, 35: 2227-2231.

[34] Zhao ZF, Chen H, Xiang HM, et al. $\left(\mathrm{La}_{0.2} \mathrm{Ce}_{0.2} \mathrm{Nd}_{0.2} \mathrm{Sm}_{0.2} \mathrm{Eu}_{0.2}\right)$ $\mathrm{PO}_{4}$ : A high-entropy rare-earth phosphate monazite ceramic with low thermal conductivity and good compatibility with $\mathrm{Al}_{2} \mathrm{O}_{3}$. J Mater Sci Technol 2019, 35: 2892-2896.

[35] Zhao ZF, Xiang HM, Dai FZ, et al. $\left(\mathrm{La}_{0.2} \mathrm{Ce}_{0.2} \mathrm{Nd}_{0.2} \mathrm{Sm}_{0.2} \mathrm{Eu}_{0.2}\right)_{2}$ $\mathrm{Zr}_{2} \mathrm{O}_{7}$ : A novel high-entropy ceramic with low thermal conductivity and sluggish grain growth rate. J Mater Sci Technol 2019, 35: 2647-2651.

[36] Zhao ZF, Chen H, Xiang HM, et al. $\left(\mathrm{Y}_{0.25} \mathrm{Yb}_{0.25} \mathrm{Er}_{0.25} \mathrm{Lu}_{0.25}\right)_{2}$ $\left(\mathrm{Zr}_{0.5} \mathrm{Hf}_{0.5}\right)_{2} \mathrm{O}_{7}$ : A defective fluorite structured high entropy ceramic with low thermal conductivity and close thermal expansion coefficient to $\mathrm{Al}_{2} \mathrm{O}_{3}$. J Mater Sci Technol 2020, 39: $167-172$.

[37] Yeh JW, Chang SY, Hong YD, et al. Anomalous decrease in
X-ray diffraction intensities of $\mathrm{Cu}-\mathrm{Ni}-\mathrm{Al}-\mathrm{Co}-\mathrm{Cr}-\mathrm{Fe}-\mathrm{Si}$ alloy systems with multi-principal elements. Mater Chem Phys 2007, 103: 41-46.

[38] Yeh JW, Chen SK, Lin SJ, et al. Nanostructured highentropy alloys with multiple principal elements: Novel alloy design concepts and outcomes. Adv Eng Mater 2004, 6: $299-303$.

[39] Razeghi M. Fundamentals of Solid State Engineering. Cham, Switzerland: Springer International Publishing, 2019.

Open Access This article is licensed under a Creative Commons Attribution 4.0 International License, which permits use, sharing, adaptation, distribution and reproduction in any medium or format, as long as you give appropriate credit to the original author(s) and the source, provide a link to the Creative Commons licence, and indicate if changes were made.

The images or other third party material in this article are included in the article's Creative Commons licence, unless indicated otherwise in a credit line to the material. If material is not included in the article's Creative Commons licence and your intended use is not permitted by statutory regulation or exceeds the permitted use, you will need to obtain permission directly from the copyright holder.

To view a copy of this licence, visit http://creativecommons. org/licenses/by/4.0/. 